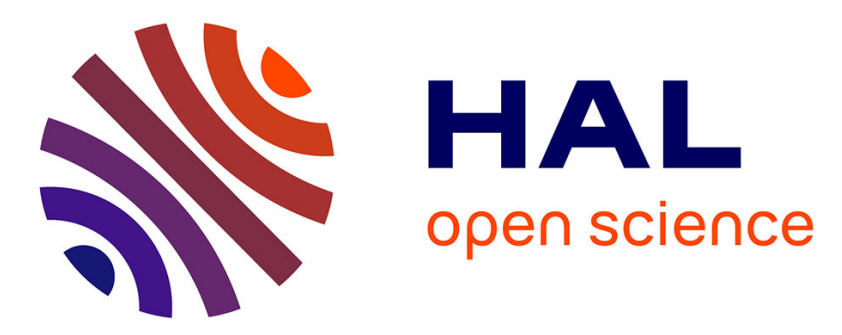

\title{
Characterisation and modelling of marine dissolved organic matter interactions with major and trace cations
}

Yoann Louis, Cédric Garnier, Véronique Lenoble, Dario Omanovic, Stéphane Mounier, Ivanka Pižeta

\section{- To cite this version:}

Yoann Louis, Cédric Garnier, Véronique Lenoble, Dario Omanovic, Stéphane Mounier, et al.. Characterisation and modelling of marine dissolved organic matter interactions with major and trace cations. Marine Environmental Research, 2009, 67, pp.100-107. 10.1016/j.marenvres.2008.12.002 . hal-01096834

\section{HAL Id: hal-01096834 \\ https://hal-univ-tln.archives-ouvertes.fr/hal-01096834}

Submitted on 5 Jan 2015

HAL is a multi-disciplinary open access archive for the deposit and dissemination of scientific research documents, whether they are published or not. The documents may come from teaching and research institutions in France or abroad, or from public or private research centers.
L'archive ouverte pluridisciplinaire HAL, est destinée au dépôt et à la diffusion de documents scientifiques de niveau recherche, publiés ou non, émanant des établissements d'enseignement et de recherche français ou étrangers, des laboratoires publics ou privés. 


\title{
Characterisation and modelling of marine dissolved organic matter interactions with major and trace cations
}

\author{
Yoann Louis $^{\mathrm{a}, 1}$, Cédric Garnier ${ }^{\mathrm{a}, \mathrm{b}, *}$, Véronique Lenoble ${ }^{\mathrm{a}}$, Dario Omanovićc ${ }^{\mathrm{c}}$, \\ Stéphane Mounier ${ }^{\mathrm{a}}$, Ivanka Pižeta ${ }^{\mathrm{c}}$ \\ a Laboratoire PROTEE, Université du Sud Toulon-Var, BP 20132, 83957 La Garde, France \\ broupe de Physico Toxico Chimie des Systèmes Naturels, Institut des Sciences Moléculaires (ISM - UMR CNRS 5255), Université Bordeaux I, 33405 Talence, France \\ ${ }^{\mathrm{C}}$ Center for Marine and Environmental Research, Ruđer Bošković Institute, P.O. Box 180, 10002 Zagreb, Croatia
}

\section{A R T I C L E I N F O}

\section{Article history:}

Received 15 September 2008

Received in revised form 5 December 2008

Accepted 8 December 2008

\section{Keywords:}

Marine environment

Dissolved organic matter

Chemical speciation

Voltammetry

Pseudopolarography

Copper complexing capacity

\begin{abstract}
A B S T R A C T
A two-step protocol (nano-filtration and reverse osmosis) was applied for natural organic matter (NOM) preconcentration of a seawater sample. Complexing affinities of the so concentrated marine dissolved NOM (DNOM) towards major and trace cations were studied by potentiometric and voltammetric titration techniques. The potentiometric titration experiments fitted by models describing and characterising the DNOM-cation interactions, revealed four distinct classes of acidic sites (pKa of 3.6, 4.8, 8.6 and 12). A total acidic sites density of $445 \mathrm{meq} / \mathrm{mol}_{\mathrm{C}}$ was estimated, with a majority (60\%) of carboxylic-like sites. Pseudopolarographic measurements revealed two distinct groups of copper complexes: labile, reducible at about $-0.2 \mathrm{~V}$; and inert, directly reducible at about $-1.4 \mathrm{~V}$. Simultaneous competition between copper, calcium and proton highlighted the presence of two classes of binding sites (density of 1.72 and $10.25 \mathrm{meq} \mathrm{mol}_{\mathrm{C}}^{-1}$, respectively, corresponding to $3 \%$ of total acidic sites). The first class was more specific to copper $\left(\log K_{\mathrm{CuL}} 9.9, \log K_{\mathrm{CaL}} 2.5, \mathrm{pKa} 8.6\right)$, whereas stronger competition between copper and calcium occurred for the second class $\left(\log K_{\mathrm{CuL}} 6.9, \log K_{\mathrm{CaL}} 5.5, \mathrm{p} K \mathrm{a} 8.2\right)$.

The binding sites characterisation was validated by the very good matching of the non-concentrated seawater sample titration data with the simulated curves obtained using the binding parameters from the concentrated sample. Furthermore, this comparison also validated the applied preconcentration protocol, highlighting its negligible influence on organic matter properties when considering copper complexation.
\end{abstract}

(c) 2008 Elsevier Ltd. All rights reserved.

\section{Introduction}

Numerous studies have been performed on dissolved natural organic matter (DNOM) coming from natural aquatic systems, in order to understand and characterise its interactions with cations and especially copper. It is now well established that metals toxicity/bioavailability towards micro- and macro-organisms is mainly conditioned by their speciation, i.e. their chemical forms in the system (Buffle, 1988; Bruland and Lohan, 2004; Hirose, 2007).

Metal-DNOM associations are complex, depending on the considered metal and organic matter, and also on the physicochemical conditions of the system: ionic strength, $\mathrm{pH}$, competition with other major and trace cations (Lu and Allen, 2002; Bruland and Lohan, 2004). Among the major divalent cations, calcium is known to

\footnotetext{
* Corresponding author. Address: Laboratoire PROTEE, Université du Sud ToulonVar, BP 20132, 83957 La Garde, France. Tel.: +33 494142099; fax: +33 494142168

E-mail addresses: louis@univ-tln.fr (Y. Louis), cgarnier@univ-tln.fr (C. Garnier), lenoble@univ-tln.fr (V. Lenoble), omanovic@irb.hr (D. Omanović), mounier @univ-tln.fr (S. Mounier), pizeta@irb.hr (I. Pižeta).

1 Tel.: +33 494142608 .
}

be the most complexant with organic matter in a marine system (Raspor et al., 1980) and so can have a dominant competitive effect with trace elements. However, a correct description of these interactions is essential to determine metal speciation, which can be calculated by using software such as FITEQL, PHREEQ, MINTEQ MINEQL, CHESS (Westall et al., 1976; Herbelin and Westall, 1999; Van der Lee and De Windt, 2000; Dudal and Gerard, 2004 and references therein) and, eventually, to predict the behaviour of these toxic trace elements in complex natural environments.

Various analytical techniques have recently been developed to better appreciate the role of marine DNOM on metal speciation (Donat and van den Berg, 1992; Wells et al., 1998; Lu and Allen, 2002; Garnier et al., 2004a; Van Leeuwen et al., 2005). The use of voltammetric tools and especially of pseudopolarography (Branica et al., 1977; Branica and Lovrić, 1997; Croot et al., 1999; Town and van Leeuwen, 2006; Chakraborty et al., 2007; Nicolau et al., 2008) allows qualitative and quantitative determination of different dissolved metal forms: electrochemically labile and inert species (reduced and released within the potential window of the method) and electro-inactive species. 
In order to predict DNOM behaviour towards metals, different theoretical models have been developed, based on a discrete or continuous distribution of DNOM binding sites. These sites are parameterized by fitting of the titration data using linear methods (Scatchard, 1949; Chau and Lum-Shue-Chan, 1974; Ružić, 1982) or more appropriate non-linear ones (Sposito, 1981; Kinniburgh et al., 1996; Tipping et al., 1998; Woolard and Linder, 1999; Town and Filella, 2002; Dudal and Gerard, 2004; Garnier et al., 2005). Due to low organic carbon content $\left(0.1-1 \mathrm{mg}_{\mathrm{C}} \mathrm{L}^{-1}\right.$; Vetter et al., 2007) associated with trace levels of metals (rarely higher than some $\mathrm{nmol} \mathrm{L}{ }^{-1}$ ), study of DNOM binding properties in unpolluted marine waters still remains a challenge. The methodology proposed and provided by the MONALISA (Matière Organique NAturelle en miLIeu SAlé) research project encompasses characterisation of concentrated DNOM marine samples by various analytical techniques (Huguet et al., 2006; Nicolau et al., 2008). The characterisation of such concentrated DNOM studied by its interaction with major and trace cations was our primary task.

The aim of this study was the determination of binding properties of marine DNOM, concentrated by nano-filtration followed by reverse osmosis, towards copper and competition effects of copper with calcium and proton. Potentiometric and pseudopolarographic titration experiments that were carried out were simultaneously fitted using the software PROSECE (Garnier et al., 2004b) to determine the binding parameters depicting the targeted DNOM reactivity.

\section{Experimental}

\subsection{Chemicals and instrumentation}

All the vessels used for potentiometric and voltammetric systems were cleaned with $10 \%$ nitric acid (Fisher Scientific, analytical grade) and rinsed with ultra-pure water (Millipore Milli-Q system). Copper solutions $\left(10,100\right.$ and $\left.1000 \mu \mathrm{mol} \mathrm{L}^{-1}\right)$ were prepared from copper nitrate (Spex Certiprep) and calcium solution $\left(0.5 \mathrm{~mol} \mathrm{~L}^{-1}\right)$ from calcium chloride (Merck, Pro Analysis). Acidification of sample, when needed, was performed using $69 \% \mathrm{HNO}_{3}$ (J.T. Baker, Trace Metal Analysis).

Nano-filtration was carried out on an Osmonics DL2540 membrane and reverse osmosis on a Filmtec SW30-2540 membrane, with a reverse osmosis equipment (Techniques Industrielles Appliquées, TIA). The used Chelex100 resin (Na-form) was provided by Sigma-Aldrich, Bio-Rad 50-100 dry mesh. The dissolved organic carbon (DOC) concentrations were determined using a Total Organic Carbon-5000A analyser (Shimadzu), with an accuracy of $0.01 \mathrm{mmol}_{\mathrm{C}} \mathrm{L}^{-1}$. The micro-titration stand (Metrohm) equipped with two Titrino 716 titrators controlled by Tinet 2.4 software was used for potentiometric titrations. The combined pH-microelectrode (Mettler, Inlab422, reference: $\mathrm{Ag} / \mathrm{AgCl} / \mathrm{KCl} 3.0 \mathrm{~mol} \mathrm{~L}^{-1}$ ) was calibrated weekly by $\mathrm{pH}$-buffer solutions and checked at least with three buffer pH's solution before each titration (HANNA 4.01, 7.01 and 10.01).

All voltammetric measurements were carried out with a voltammetric analyser PGSTAT12 (EcoChemie) with GPES 4.9 software (Eco Chemie, Utrecht) coupled with a three electrodes system of 663VA Stand (Metrohm, Swiss). The working electrode was a static mercury drop electrode (SMDE) (size $1,0.25 \mathrm{~mm}^{2}$ of area). Potentials were determined vs. a reference electrode of $\mathrm{Ag} /$ $\mathrm{AgCl}$ (sat. $\mathrm{KCl}$ ), and a Platinum wire was used as a counter electrode. The solution, supported in a Teflon electrochemical cell, was stirred with a Teflon rotating stirrer at $3000 \mathrm{rpm}$. The room temperature was regulated at $25 \pm 2{ }^{\circ} \mathrm{C}$. $\mathrm{pH}$ was controlled by a $\mathrm{pH}$ meter (Metrohm, $713 \mathrm{PHM}$ ) with a combined pH-micro-electrode (Mettler, Inlab422, reference electrode: $\mathrm{Ag} / \mathrm{AgCl} / \mathrm{KCl}$
$3.0 \mathrm{~mol} \mathrm{~L}^{-1}$ ). Copper additions were carried out using three automatic burettes (Tecan, Cavro XE 1000 syringe pumps, Swiss).

The following conditions were used for Differential Pulse Anodic Stripping Voltammetry (DPASV) measurements: pulse amplitude $25 \mathrm{mV}$; potential step increment $2.5 \mathrm{mV}$; time between pulses $0.1 \mathrm{~s}$; pulse duration $0.05 \mathrm{~s} ; 300 \mathrm{~s}$ of deposition time decomposed in two steps: $297 \mathrm{~s}$ at a deposition potential $E_{\mathrm{dep}}$ and $3 \mathrm{~s}$ at a second deposition potential $E_{\mathrm{dep} 2}=-1.6 \mathrm{~V}$. This procedure, using a strong negative potential, was established to desorb the layer of natural organic matter (also called surface active substances) which may adsorb at the electrode surface and may produce interferences during the stripping step (Louis et al., 2008). After this deposition step, the potential was scanned from $-0.6 \mathrm{~V}$ to $0.05 \mathrm{~V}$. This total procedure is used to measure labile copper, i.e. mostly the free copper and inorganic complexes. For each electrochemical experiment, $30 \mathrm{~mL}$ of a sample was placed in the voltammetric cell and dissolved oxygen was removed from the solution prior to analysis by purging with ultra-pure nitrogen for at least $15 \mathrm{~min}$, and a water-saturated nitrogen blanket was maintained above the surface during the whole experiment.

Total metal concentrations were determined with an accuracy of $10 \%$ by standard additions of $\mathrm{Cu}$ by DPASV measurements $\left(E_{\mathrm{dep}}=-1.5 \mathrm{~V}\right.$ ), after UV-irradiation (Hanovia, $450 \mathrm{~W}$ medium $\mathrm{Hg}$ pressure, $12 \mathrm{~h}$ ) at acidic $\mathrm{pH}(<2)$ (Capodaglio et al., 1995). Major cation concentrations were analysed by ionic chromatography (DIONEX, DX-120), previously calibrated using $\mathrm{Ca}\left(\mathrm{NO}_{3}\right)_{2}$, $\mathrm{Mg}\left(\mathrm{NO}_{3}\right)_{2}, \mathrm{NaNO}_{3}$ and $\mathrm{KNO}_{3}$ calibration standard solutions (Fisher Scientific). For in situ salinity and $\mathrm{pH}$ measurements, a multiparameters probe (Hydrolab, Minisonde 4a) was used.

\subsection{Sampling and sample preparation}

The analysed seawater was sampled in Balaguier bay (near Toulon, south of France, coordinates $43^{\circ} 05^{\prime} 51.70 \mathrm{~N}, 5^{\circ} 54^{\prime} 28.50 \mathrm{E}$, May 22th 2006). The sample was taken $1 \mathrm{~m}$ under the surface using a Teflon membrane pump (Retsch Gmbh) running on pressurised nitrogen gas, and filtered with an online $0.22 \mu \mathrm{m}$ Teflon filter (Whatman, Polycap 150TF). The interest of this site relies on the fact that it is a semi closed area with anthropogenic activities (military port, tourism and aquacultures activities).

Nine hundred and fifty liter of filtered sample was stored in precleaned HDPE Nalgene bottles ( 20 and $50 \mathrm{~L}$ ) at $4{ }^{\circ} \mathrm{C}$ in the dark before concentration. One liter of this filtered sample was devoted to the analysis of DNOM reactivity, and stored in dark at $4{ }^{\circ} \mathrm{C}$ after spiking with $\mathrm{NaN}_{3}\left(100 \mu \mathrm{L}\right.$ of $\left.0.1 \mathrm{~mol} \mathrm{~L}^{-1}\right)$ to prevent any biological activity. Salinity was 37, DOC content $0.09 \mathrm{mmol}_{\mathrm{C}} \mathrm{L}^{-1}$, and total $\mathrm{Cu}$ concentration $14.8 \mathrm{nmol} \mathrm{L}^{-1}$, i.e. in the range of concentration for coastal areas (Kogut and Voelker, 2001). Indeed, in the same bay of Toulon, total dissolved copper concentrations as high as $45 \mathrm{nM}$ have been recorded in summer 2006 (Rossi and Jamet, 2008).

Within the framework of the French research project MONALISA, a new methodology has been developed to concentrate marine DNOM from large volumes (500-1000 L), using two concentrations steps: (1) with osmosis equipment (TIA) by nano-filtration (Osmonics DL2540, pore size 150-300 Da) followed by (2) reverse osmosis (Filmtec SW30-2540, pore size <100 Da) (Huguet et al., 2006; Nicolau et al., 2008). The concentration step was necessary to obtain sufficient quantity of DNOM for subsequent characterisation of its properties using ${ }^{13} \mathrm{C}$ and ${ }^{113} \mathrm{Cd}$ nuclear magnetic resonance spectroscopy, pyrolysis-gas chromatography-mass spectrometry and high pressure size exclusion chromatography (analysis performed by the different MONALISA participants), and to better describe DNOM affinities towards major and trace cations. Various difficulties were encountered in the DNOM concentrating process. Modification of DNOM properties and increase of salt quantity during the concentration protocol were unwanted 
side effects which were minimized by using the two-step process involving nano-filtration and reverse osmosis. The first step involved the concentration of $940 \mathrm{~L}$ of filtered sample using nano-filtration to reach $32 \mathrm{~L}$. MilliQ water was added at the end of the process to decrease the salinity, reaching a salinity value of 10.2 and a DOC content of $0.9 \mathrm{mmol}_{\mathrm{C}} \mathrm{L}^{-1}$. In a second step, the $32 \mathrm{~L}$ of nano-filtered sample was concentrated by reverse osmosis to end with $10.5 \mathrm{~L}$ of concentrated sample at a salinity of 28 , a DOC content of $2.53 \mathrm{mmol}_{\mathrm{C}} \mathrm{L}^{-1}$, representing about $31.4 \%$ of the total carbon initially present in the sample, which corresponds to a classical recovery for this kind of technique (Vetter et al., 2007) and a total copper concentration of $1.4 \mu \mathrm{mol} \mathrm{L}^{-1}$. This concentrated sample $(1.5 \mathrm{~L})$ was devoted to the analysis of DNOM reactivity, and stored in dark at $4{ }^{\circ} \mathrm{C}$ after spiking with $\mathrm{NaN}_{3}\left(100 \mu \mathrm{L}\right.$ of $\left.1 \mathrm{~mol} \mathrm{~L}^{-1}\right)$ to prevent any biological activity.

To remove major and trace divalent cations, the sample was left in contact with a Chelex100 resin, until the calcium and magnesium concentrations reached the ionic chromatographic detection limit $\left(1 \mu \mathrm{mol} \mathrm{L}^{-1}\right)$. Finally the total copper, cadmium and lead concentrations detectable by the used technique (DPASV), were below $1 \mathrm{nmol} \mathrm{L}^{-1}$. If some metals remained after this Chelex treatment (e.g. $\mathrm{Fe}^{3+}$ ), it should not significantly influence the $\mathrm{Cu} / \mathrm{DNOM}$ association as they form very strong and specific complexes with DNOM (Bruland and Lohan, 2004). The final DOC concentration was of $1.2 \mathrm{mmol}_{\mathrm{C}} \mathrm{L}^{-1}$. Subsequent potentiometric and voltammetric analysis were performed on this purified concentrated sample, as well as on the filtered (but not concentrated) sample also put in contact with Chelex100 resin under the same conditions. Final major inorganic ions content was similar to seawater (salinity 37 ), replacing divalent cations by sodium.

\subsection{Experimental design and modelling}

In order to define the reactivity of the studied DNOM towards proton, potentiometric titrations were performed. Acid-base titration was carried out on $40 \mathrm{~mL}$ of the concentrated DNOM following the procedure detailed elsewhere (Garnier et al., 2004c). Briefly, the experiment was conducted in a thermostated cell at $25 \pm 0.2^{\circ} \mathrm{C}$ connected to a cryostat regulating system (Fisher Scientific), using $\mathrm{NaOH}\left(0.10 \mathrm{~mol} \mathrm{~L}^{-1}\right.$, from $\mathrm{NaOH} 10 \mathrm{~mol} \mathrm{~L}^{-1}$ concentrated Fisher Chemicals) and $\mathrm{HNO}_{3}\left(0.2 \mathrm{~mol} \mathrm{~L}{ }^{-1}\right.$, from $\mathrm{HNO}_{3} 69 \%$ J.T. Baker) standardised $\mathrm{CO}_{2}$-free solutions, under stirring and streamed by an ultra-pure nitrogen flow (water-saturated and decarbonated using $1 \mathrm{~mol} \mathrm{~L}^{-1} \mathrm{NaOH}$ solution).

DNOM acidic properties were characterised using a discrete model of acidic sites distribution $\left(L_{\mathrm{Hi}}\right)$, each site defined by two parameters: a site density $\left(L_{\mathrm{HiT}}\right.$ in meq $\left.\mathrm{mol}_{\mathrm{C}}^{-1}\right)$ and a stability constant $\left(\mathrm{pKa}_{\mathrm{i}}\right)$ (Lu and Allen, 2002; Garnier et al., 2004c). Obtained experimental potentiometric data were fitted using the software PROSECE (available on request, free of charge) which has already been successfully applied for potentiometric studies (Garnier et al., 2004c, 2005; Lenoble et al., 2008). The fitting resulted in the determination of the optimal number of acidic sites with corresponding optimised protonation/stability constant ( $\mathrm{pKa}$ ) and density $\left(L_{T}\right)$ values. From these values, DNOM carboxylic-like sites with acidic pKa values, and phenolic-like sites with more basic pKa values can be differentiated.

Three series of experiments were carried out on the concentrated sample, to analyse the reactivity of the studied DNOM towards $\mathrm{Cu}^{2+}$ and competition effects of $\mathrm{Cu}^{2+}$ with $\mathrm{Ca}^{2+}$ and $\mathrm{H}^{+}$.

The first experiment performed on $30 \mathrm{~mL}$ of the concentrated sample at pH 8.2 resulted in construction of a pseudopolarogram ( $E_{\text {dep }}$ from $-1.5 \mathrm{~V}$ to $0.1 \mathrm{~V}$ ). Then, a known quantity of copper was added to the sample. After waiting at least $1 \mathrm{~h}$ to reach equilibrium, another pseudopolarographic measurement was carried out. Subsequently, several copper additions were performed in log- arithmic increments (Garnier et al., 2004a,b), to cover a range from $10 \mathrm{nmol} \mathrm{L}^{-1}$ to $50 \mu \mathrm{mol} \mathrm{L}^{-1}$ (divided in 30 additions) in order to study the variation of copper speciation with its increasing concentration.

A second experiment corresponding to a calcium titration was performed on the same sample with a fixed total copper concentration of $12.5 \mu \mathrm{mol} \mathrm{L}^{-1}$ and with six additions of calcium going from $1 \mu \mathrm{mol} \mathrm{L}{ }^{-1}$ to $20 \mathrm{mmol} \mathrm{L}^{-1}$ (i.e. twice the natural marine concentration). This copper concentration was chosen as the middle of the range covered in the previous experiment.

A third experiment was carried out by varying the $\mathrm{pH}$ from 8.7 to 3.5 by addition of $\mathrm{HNO}_{3}$ and $\mathrm{NaOH}$ in the sample with a total concentration of copper fixed to $4 \mu \mathrm{mol} \mathrm{L}^{-1}$, chosen according to first pseudopolarographic experiment results.

The simultaneous fitting of the data obtained by these three experiments with the software PROSECE gave the complexation parameters of the studied DNOM, describing its affinities towards $\mathrm{Cu}^{2+}, \mathrm{Ca}^{2+}$ and $\mathrm{H}^{+}$, taking account of cation competition effects. To minimize the side effects on copper anodic stripping peak produced by organic matter adsorption on the mercury working electrode, a potential jump to $-1.6 \mathrm{~V}$ was applied at the end of the accumulation time during $3 \mathrm{~s}$ (Louis et al., 2008). For all voltammetric experiments, peak area was used as a characteristic signal value. Corresponding copper concentrations (or portions) plotted on all graphs were calculated according to sensitivity obtained in organic-free seawater sample (UV-irradiated sample during $12 \mathrm{~h}$ ). The same sensitivity $\left(0.0067 \pm 0.0001 \mathrm{AV} \mathrm{L} \mathrm{mol}^{-1}\right)$ was obtained at both deposition potentials $(-1.5 \mathrm{~V}$ and $-0.5 \mathrm{~V})$ for the whole analytical window $\left(10 \mathrm{nmol} \mathrm{L}^{-1}-30 \mu \mathrm{mol} \mathrm{L}^{-1}\right)$.

Due to DNOM structural heterogeneity, mono- and multi-dentate ligands could be expected (Tipping et al., 1998). However, due to experimental and fitting uncertainties, it has been shown in a theoretical study that the corresponding binding parameters are often inaccurately determined (Garnier et al., 2005). So, in this study DNOM binding properties towards cations were modelled using a discrete distribution of mono-dentate binding ligands $\left(L_{\mathrm{Mi}}\right)$, each defined by four parameters: a site density $\left(L_{\mathrm{MiT}}\right.$ in meq $\mathrm{mol}_{\mathrm{C}}^{-1}$ ) and stability constants (referring to the free cation concentrations) towards copper $\left(K_{\mathrm{CuLi}}\right)$, calcium $\left(K_{\mathrm{CaLi}}\right)$ and proton $\left(\mathrm{p} K \mathrm{a}_{\mathrm{i}}\right)$ (Garnier et al., 2004a; Sposito, 1981). Inorganic chemical composition of the solution was taken into account to calculate the inorganic speciation of copper and other cations, using thermodynamic stability constants from MINEQL and MINTEQ databases. This categorization of ligands is a simplification of true chemical structures. Those are virtual entities used to simultaneously describe the interactions of DNOM binding sites with major and trace cations, taking account of cation competition effects expected in marine water. PROSECE was used to optimise the values of these unknown parameters by simultaneously fitting all the obtained experimental data.

\section{Results and discussion}

\subsection{DNOM acidic properties}

Several discrete models of sites distribution ranging from 2 to 6 were tested by PROSECE to fit the experimental potentiometric titration points (Fig. 1). An optimal number of four acidic sites was selected for these titration data, minimizing errors on titration $\mathrm{pH}$ values calculated from differences between experimental and calculated pH values, as described in Garnier et al. (2004c).

The total acidic sites density of analysed DNOM was estimated as $445 \pm 15 \mathrm{meq} \mathrm{mol}_{\mathrm{C}}^{-1}$ (Table 1 ). This high acidic content, e.g. $2.7 \times$ higher than fresh water DNOM studied by Lu and Allen (2002), has no clear explanation. The same fitting procedure was successfully 


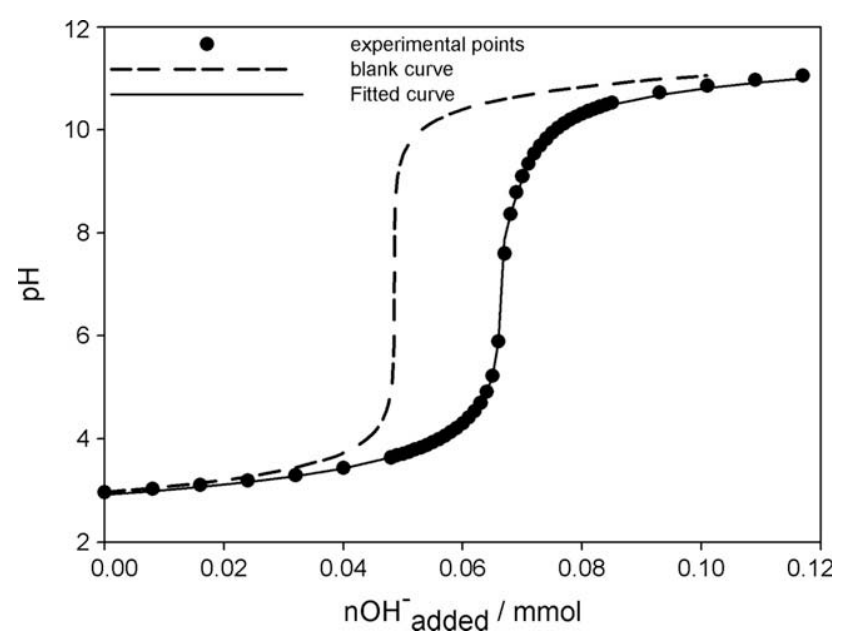

Fig. 1. Potentiometric titration of the concentrated DNOM sample (closed circle; $D O C=1.2 \mathrm{mmol}_{C} \mathrm{~L}^{-1}$ ) and the fitting curve obtained by PROSECE (solid line, four ligands characterised in Table 1) as a function of $n_{\mathrm{OH}-}$ added; dashed line represents the titration curve obtained in absence of DNOM complexation in MilliQ water (with $I=0.7 \mathrm{M}$ ).

applied to standard organic matter (Garnier et al., 2004c). In that study, a limit for total acidic site concentrations of 0.04 meq was estimated for a correct determination of acido-basic parameters in low DOC conditions, under which an overestimation of the phenolic-like sites can be expected, compared to the carboxylic ones. In this study, obtained results do not show this unexpectedly high proportion of phenolic sites and total acidic sites content is in the range of the defined limit. Two classes of acidic sites can be differentiated depending on their pKa (Table 1 ): around $60 \%$ of carboxylic-like $\left(L_{\mathrm{H} 1}\right.$ and $L_{\mathrm{H} 2}$ with a stability constant pKa of $3.6 \pm 0.1$ and $4.8 \pm 0.1$, respectively) and $40 \%$ of phenolic-like $\left(L_{\mathrm{H} 3}\right.$ and $L_{\mathrm{H} 4}$ with a stability constant $\mathrm{pKa}$ of $8.6 \pm 0.1$ and $12 \pm 0.4$, respectively). The most acid site $\left(L_{\mathrm{H} 1}\right)$ was the most abundant and represented about $50 \%$ of the total acidic site density. These determined parameters are not used for determinations of the complexing parameters with cations, considering (as shown by Buffle (1988)) that the efficient complexing sites represent only a small fraction (some $\%$ ) of the acidic sites. A comparable approach was used by Lenoble et al. (2008) to investigate acidic and complexing properties of organic matter.

\subsection{Pseudopolarography experiments}

Selected normalized pseudopolarograms of copper obtained during titration of the concentrated seawater sample are presented in Fig. 2. Normalized pseudopolarograms are constructed as ratio

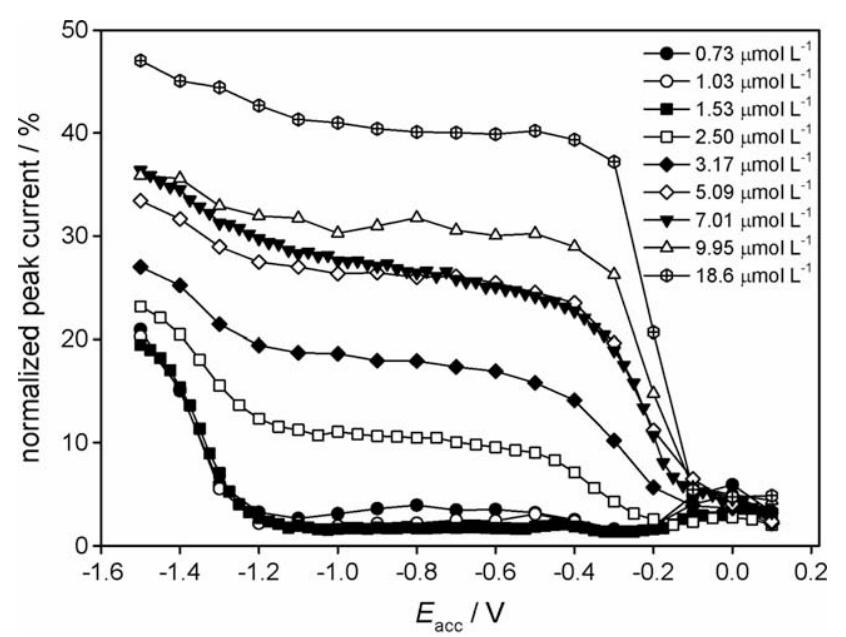

Fig. 2. Pseudopolarograms of interest obtained by DPASV for logarithmic copper additions on the concentrated sample $(\mathrm{pH}=8.2)$ represented as the fraction of measured electro-active copper (compared to total added copper) as a function of deposition potential. $t_{\mathrm{dep}}=297 \mathrm{~s}$ at $E_{\mathrm{dep}}$ (from $-1.5 \mathrm{~V}$ to $\left.0.1 \mathrm{~V}\right)+3 \mathrm{~s}$ at $E_{\text {dep2 }}=-1.6 \mathrm{~V}$.

of peak currents obtained in the presence and in the absence of organic ligands (UV-digested). From these pseudopolarograms, two well resolved waves can be differentiated: one at a very negative deposition potential $E_{\text {dep }}=-1.4 \mathrm{~V}$, and another at a more positive potential $E_{\mathrm{dep}}=-0.2 \mathrm{~V}$. Pseudopolarographic waves obtained at the more negative potential correspond to direct reduction of inert copper complexes. Pseudopolarograms having two or more waves were registered in many papers if a wide range of deposition potentials was applied (e.g. Croot et al., 1999; Luther et al., 2001; Louis et al., 2008). According to "chelate scale" presented by the group of Luther III (Luther et al., 2001), thermodynamic stability constant $\log K$ of these complexes is higher than 40 . Similar copper pseudopolarographic waves were registered in non-concentrated samples (Luther et al., 2001; Louis et al., 2008).

The more positive pseudopolarographic wave (at $-0.2 \mathrm{~V}$ ) corresponds to a reduction of labile mostly inorganic copper complexes, while kinetically labile, relatively weak organic complexes dissociated within the diffusion layer, contributed in some extent as well. The potential plateau more negative than pseudopolarographic waves of labile copper $(<-0.3 \mathrm{~V})$ is usually used for determination of copper complexing capacity. For this concentrated sample, voltammetric signals (peak areas) obtained by accumulation at $-0.5 \mathrm{~V}$ were used for determination of copper complexing parameters. Addition of copper up to $1.53 \mu \mathrm{M}$ produced only an increase of the more negative wave. As the diffusion coefficient of the formed inert metal complexes reducible at more negative potential

Table 1

Properties of acidic and binding sites of the concentrated DNOM. Concentration of the acidic sites $\left(L_{\mathrm{Hi}}\right)$ and the associated acidic stability constant ( $\mathrm{pKa}$ ) are obtained by PROSECE fitting of experimental potentiometric data; and the two binding site density $L_{\mathrm{M} 1}$ and $L_{\mathrm{M} 2}$ and their stability constants (towards copper, calcium and proton) are defined after PROSECE simultaneous fitting of copper logarithmic additions, calcium addition and $\mathrm{pH}$ variation.

\begin{tabular}{|c|c|c|c|c|c|c|c|}
\hline & $L_{\mathrm{H} 1}$ & $L_{\mathrm{H} 2}$ & $L_{\mathrm{H} 3}$ & $L_{\mathrm{H} 4}$ & Carboxylic type & Phenolic type & Total acidic sites \\
\hline \multirow[t]{2}{*}{$\begin{array}{l}\text { Acidic sites } \\
L_{\mathrm{HiT}}\left(\mathrm{meq} \mathrm{mol}_{\mathrm{C}}^{-1}\right) \\
\mathrm{p} K \mathrm{a}\end{array}$} & $\begin{array}{c}210 \pm 11 \\
3.6 \pm 0.1\end{array}$ & $\begin{array}{l}54 \pm 2 \\
4.8 \pm 0.1\end{array}$ & $\begin{array}{c}80 \pm 1 \\
8.6 \pm 0.1\end{array}$ & $\begin{array}{c}101 \pm 1 \\
12.0 \pm 0.4\end{array}$ & $264 \pm 13$ & $181 \pm 2$ & $445 \pm 15$ \\
\hline & & & & $L_{\mathrm{M} 1}$ & & & $L_{\mathrm{M} 2}$ \\
\hline \multicolumn{8}{|l|}{ Binding sites } \\
\hline$L_{\text {Miт }}\left(\right.$ meq $\left.\operatorname{mol}_{\mathrm{C}}^{-1}\right)$ & & & & $1.72 \pm 0.13$ & & & $10.2 \pm 3.2$ \\
\hline $\log K_{\mathrm{CuL}}$ & & & & $9.9 \pm 0.1$ & & & $6.9 \pm 0.1$ \\
\hline $\log K_{\mathrm{CaL}}$ & & & & $2.5 \pm 0.4$ & & & $5.5 \pm 0.6$ \\
\hline $\mathrm{pKa}$ & & & & $8.6 \pm 0.1$ & & & $8.2 \pm 0.3$ \\
\hline
\end{tabular}


is not known, it is not possible to know if this wave corresponds to all formed inert copper complexes, or there are complexes which are not reducible at the scanned deposition potential window. The labile form first appeared when total added copper concentration was $2.5 \mu \mathrm{M}$, indicating the range of concentrations of ligands forming inert copper complexes (see next section for titration curve and results). Detailed description of pseudopolarograms was omitted here because pseudopolarographic curves served only as a fingerprint of the sample and are used for the selection of the appropriate deposition potential for the rest of the experiment.

\subsection{DNOM binding properties towards copper, calcium and proton}

The difference between experimental points and non-complexing dashed line (Fig. 3A) clearly showed the strong affinity of the studied marine DNOM for copper in the scanned analytical range at natural $\mathrm{pH}$. With calcium additions, copper was progressively dissociated from the DNOM binding sites, but even at a calcium concentration twice the natural marine content, about $2 \mu \mathrm{mol} \mathrm{L}^{-1}$ of copper still remained bound to DNOM (Fig. 3B on the left). Therefore, a part of the DNOM binding sites was specific to $\mathrm{Cu}^{2+}$. This observed tendency is in agreement with results previously obtained by Lu and Allen (2002) for $\mathrm{Cu}^{2+}$ competition with $\mathrm{Ca}^{2+}$ in a freshwater DNOM.

Similarly, acidification of the sample continuously decreased the strength of $\mathrm{DNOM} / \mathrm{Cu}^{2+}$ interactions, beginning at $\mathrm{pH} 8$ to end with negligible affinities at pH 3.5 (Fig. 3B, on the right). If DNOM binding sites were of carboxylic-like proton affinities, copper dissociation would appear only at very acidic $\mathrm{pH}$ where $\mathrm{H}^{+}$/ $\mathrm{Cu}^{2+}$ competition could be efficient. It indicates that the DNOM sites involved in the copper binding have quite strong affinities towards protons, so probably of phenolic-like nature, which is also in agreement with results of Lu and Allen (2002) for the same type of competition experiments. The slight increase of inorganic copper fraction at basic $\mathrm{pH}$ corresponds to a higher competition of inorganic major ligands $\left(\mathrm{OH}^{-}, \mathrm{CO}_{3}^{2-}, \ldots\right)$.

All the experimental data were fitted simultaneously with PROSECE. Inorganic species were defined from the salinity, replacing $\mathrm{Ca}^{2+}$ and $\mathrm{Mg}^{2+}$ by $\mathrm{Na}^{+}$as the sample was left in contact with Chelex100 resin used in the sodium form (so replacing $\mathrm{Ca}^{2+}$ and $\mathrm{Mg}^{2+}$ by $\mathrm{Na}^{+}$in solution). A distribution of two binding sites was

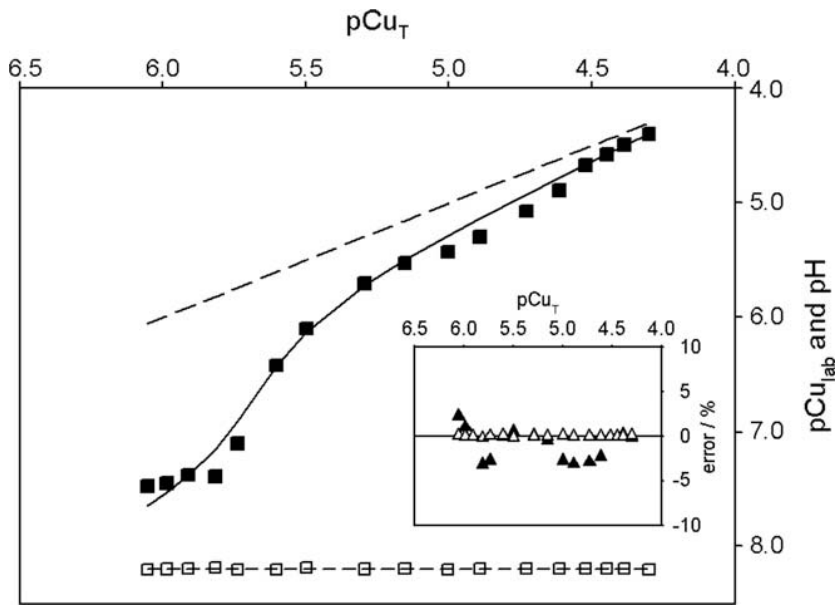

Fig. 3A. Copper logarithmic additions to the concentrated sample at $\mathrm{pH}=8.2$ (closed squares) at $E_{\mathrm{dep}}=-0.5 \mathrm{~V}, \mathrm{pH}$ values (open squares) and PROSECE corresponding fitting (solid and dashed line). $\mathrm{pCu}_{\mathrm{T}}$ represents - log [total copper] and $\mathrm{pCu}_{\text {lab }}$ is - log [electro-labile measured copper]. In inset, error on $\mathrm{pH}$ (open triangles) and copper (closed triangles) fitting. The large dashed line represents the theoretical curve of non-complexed metal.

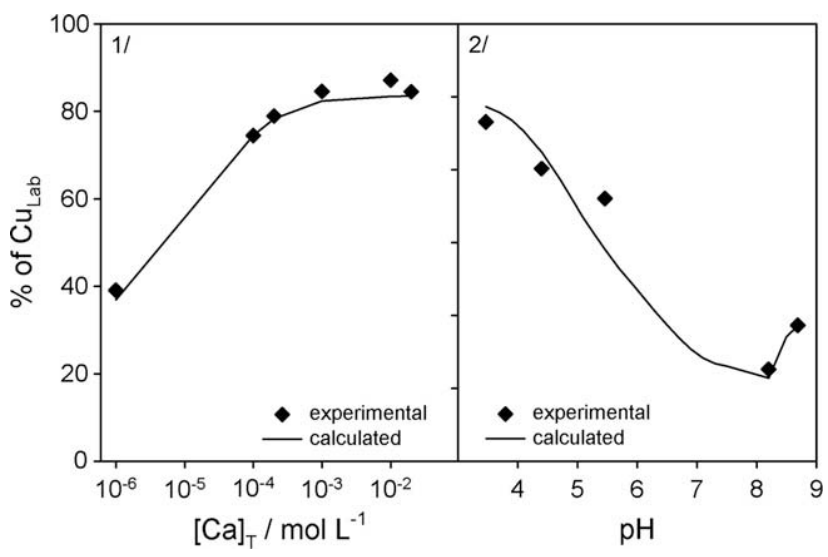

Fig. 3B. Labile copper fraction in the concentrated sample (closed diamonds) and corresponding fitted lines (solid line) as a function of: (1) on the left: total added calcium concentration with a total concentration of copper $[\mathrm{Cu}]_{\mathrm{T}}=12.5 \mu \mathrm{mol} \mathrm{L}{ }^{-1}$. $\mathrm{pH}=8.2$, (2) on the right: $\mathrm{pH}$ variation for a total concentration of copper $[\mathrm{Cu}]_{\mathrm{T}}=4 \mu \mathrm{mol} \mathrm{L}^{-1}$.

optimal to simulate these different titrations. It has to be underlined here, that the complexing properties of theses sites are independent from the acidic sites properties previously determined, because only ligands accounted for copper complexation were considered in the fitting procedure. The optimised values of the binding parameters (site densities and stability constants) are summarized in Table 1 and the fitted curves are shown in Figs. $3 \mathrm{~A}$ and $3 \mathrm{~B}$. In comparison with the total acidic site density $\left(L_{\mathrm{HT}}=445 \pm 15 \mathrm{meq}^{-1} \mathrm{~mol}_{\mathrm{C}}^{-1}\right.$, the total metal binding site density $\left(L_{\mathrm{MT}}=11.9 \pm 3.3 \mathrm{meq} \mathrm{mol}_{\mathrm{C}}^{-1}\right)$ represents $<3 \%$ as already shown for natural organic matter (Buffle, 1988). The reactivity of the studied DNOM can be characterised by a "strong" complexing site $\left(L_{\mathrm{M} 1}\right)$ specific to copper (Table $1, \log K_{\mathrm{CuL}}=9.9 \pm 0.1$ ) with a low affinity for calcium $\left(\log K_{\mathrm{CaL}}=2.5 \pm 0.4\right.$ ). Previous studies have already shown the presence of strong ligands in marine water with the copper stability constant equal or higher than $10^{10}$ using ASV or Ad-CSV measurements, but without taking account of $\mathrm{Ca}^{2+}$ and $\mathrm{H}^{+}$competitive effects (Donat and Van Den Berg, 1992; Kogut and Voelker, 2001; Wells et al., 1998). As DOC contents are rarely mentioned in these papers, it is quite difficult to compare the obtained results in terms of site density. Using a mean DOC value of around $0.08 \mathrm{mmol}_{\mathrm{C}} \mathrm{L}^{-1}$ expected for unpolluted coastal seawaters (Vetter et al., 2007), the optimised $L_{\mathrm{M} 1}$ concentration $\left(138 \pm 10 \mathrm{nmol} \mathrm{L}^{-1}\right)$ is still comparable to values obtained in previously cited literature. The second site $\left(L_{\mathrm{M} 2}\right)$ is less specific to copper $\left(\log K_{\mathrm{CuL}}=6.9 \pm 0.1\right)$, with high calcium competition effect $\left(\log K_{\mathrm{CaL}}=5.5 \pm 0.6\right)$. It can be pointed out, that the binding site density and the stability constant $\log K_{\mathrm{CaL}}$ determined for the second site $\left(L_{\mathrm{M} 2}\right)$ are in good agreement with those found by Iglesias et al. (2003) but obtained for a soil extracted fulvic acid at a pH of 6.5 (mean $\log K_{\mathrm{CaL}}=5.41$ and $\left[L_{\mathrm{M} 2}\right]$ about $7.8 \mathrm{meq} \mathrm{mol}_{\mathrm{C}}^{-1}$ ). Hirose (2007) mentioned some $\log K_{\mathrm{CaL}}$ values this time for marine DNOM and ranging from 3.1 to 3.9 , but those values are not experimentally determined as they are obtained using the linear free-energy relationships (LFER). This concept assumes that marine natural organic ligands are non-specific and non-selective regarding the complexation of metal ions such as aminopolycarboxylic acids, so DOM reactivity could be described by artificial organic ligands as EDTA (Hirose, 1994). Results obtained in our study for a marine DNOM did not confirm this hypothesis, but are analogous to those of Lu and Allen (2002) which suggested that $\mathrm{Ca}^{2+}$ and $\mathrm{Mg}^{2+}$ preferentially bind carboxylic-like sites contrary to $\mathrm{Cu}^{2+}$ which could be associated strongly with phenolic-like sites, explaining the low competitive effect between copper and major divalent cations for 
DNOM strong ligand. Another study in model estuarine conditions obtained no major divalent cations effect on the complexation of $\mathrm{Cu}^{2+}$ by an isolated peat humic acid (Hamilton-Taylor et al., 2002), which supports the specificity of the strong ligand obtained in this work. Considering their pKa values (around 8.4), both binding sites have affinity towards proton of phenolic-like type.

\subsection{DNOM model application for natural non-concentrated sample}

The aim of this study is to demonstrate the use of the optimised parameters obtained in previous experiments in speciation software such as MINEQL (Westall et al., 1976) or MOCO (Gonzalez et al., 2001) in defining the role of marine DNOM in trace metals speciation. It is necessary to determine if DNOM reactivity has been altered or not during the different concentration steps, especially its interactions towards cations. An experiment with logarithmic additions of copper was performed on the nonconcentrated filtered seawater sample, previously treated with Chelex100 resin. The added copper concentrations spanned the range from $10 \mathrm{nmol} \mathrm{L}^{-1}$ to $3 \mu \mathrm{mol} \mathrm{L}-1$ (Fig. 4).

MINEQL was used to simulate copper speciation which corresponds to the performed experiment. The chemical system was defined taking account of the inorganic species, copper concentration range and $\mathrm{pH}$. Copper-DNOM complexing parameters for the two groups of complexing sites (ligands) obtained in concentrated sample were incorporated in the MINEQL model taking into account DOC content of $0.09 \mathrm{mmol}_{\mathrm{C}} \mathrm{L}^{-1}$. It can be seen (Fig. 4) that model titration curve fitted the experimental data well, without any adjustment of the binding parameters, and so validated the characterisation protocol used in this study and the optimised values. Consequently, the fraction of organic matter non-concentrated by means of nano-filtration and reverse osmosis does not present differentiable binding properties. One previous study has already shown that reverse osmosis concentration of DNOM does not modify its ability to complex trace metals and so regulate their toxicity towards micro-organisms, but it has been performed on freshwater sample without determining the DNOM binding properties (De Schamphelaere et al., 2005).

Therefore, once the different experiments allowed the definition of the studied DNOM binding parameters, this DNOM model integrated in MINEQL was used to predict the copper speciation in a marine environment. Organic and inorganic forms of copper were calculated depending on the $\mathrm{pH}$ in real conditions, i.e. this

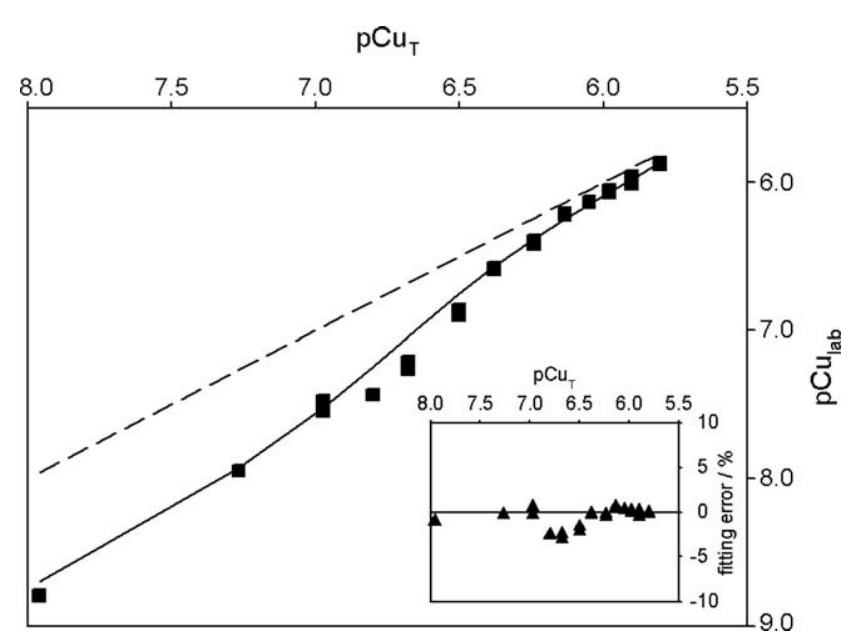

Fig. 4. Copper logarithmic addition on the filtered $\left(\mathrm{DOC}=0.09 \mathrm{mmol}_{\mathrm{C}} \mathrm{L}^{-1}\right.$ ) DNOM sample (closed squares) and MINEQL simulation (solid line). $E_{\mathrm{dep}}=-0.5 \mathrm{~V}$. Inset: percentage of error on the copper fitting (closed triangles). The large dashed line represents the theoretical curve of non-complexed metal.

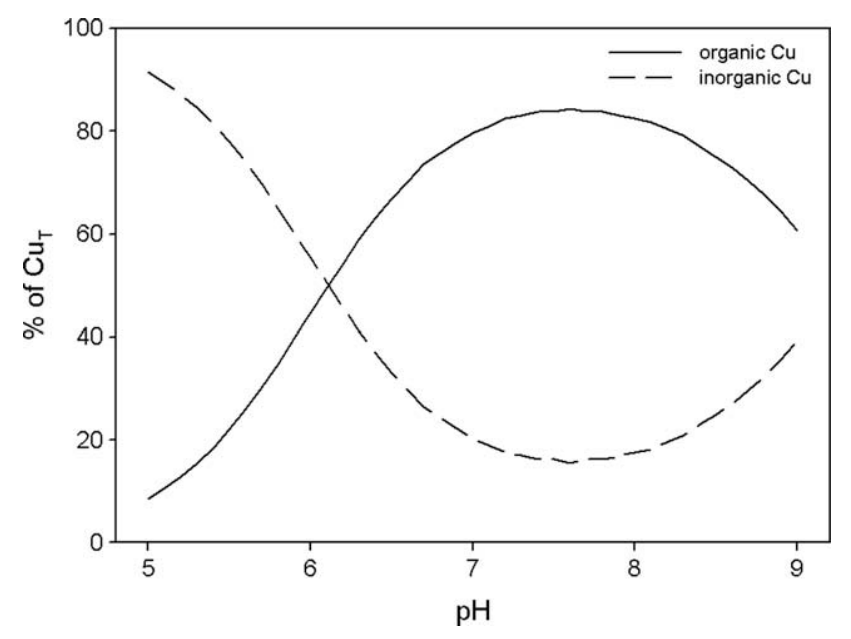

Fig. 5. Simulated distribution of inorganic (labile) copper complexes (dotted line) and organic (inert) copper complexes (solid line) in seawater conditions as a function of $\mathrm{pH}$. DNOM complexing parameters obtained in this work were used with MINEQL simulation.

time, with major cations and anion concentrations, DOC content $\left(0.09 \mathrm{mmol}_{\mathrm{C}} \mathrm{L}^{-1}\right)$ and $[\mathrm{Cu}]_{\mathrm{T}}\left(14.8 \mathrm{nmol} \mathrm{L}^{-1}\right)$ as measured in the filtered sample before concentration. Among the major cations, only the $\mathrm{Ca}^{2+} /$ DNOM association is taken into account as it is known to be the predominant one (Raspor et al., 1980). Distribution was calculated in the $\mathrm{pH}$ range from 5 to 9 , but looking at natural marine waters conditions, it appears that between $\mathrm{pH} 7.5$ and 8.3 more than $80 \%$ of total copper was complexed as organic forms (Fig. 5). This percentage could seem quite low, compared to those from studies in open oceans (Bruland and Lohan, 2004 and references therein), but it must be linked to the oligotrophic character of our studied site associated with a relatively high $\mathrm{Cu}$ content, which corroborates previous results (Louis et al., 2008). Compared to the value of $10^{-11} \mathrm{~mol} \mathrm{~L}^{-1}$, defined by Sunda et al. (1987) as the limit of copper toxicity toward marine micro-organisms, the calculated free copper $\left(\mathrm{Cu}^{2+}\right)$ concentrations ranged from 1.6 to $5 \times 10^{-11}$ mol L ${ }^{-1}$, meaning that the studied coastal seawater, impacted by some anthropogenic inputs, could be slightly toxic.

\section{Conclusion}

In this study, a specific protocol was used in order to characterise coastal marine DNOM properties toward copper, calcium and proton. This protocol consisted of firstly concentrating a natural seawater sample by nano-filtration followed by reverse osmosis to work with higher amounts of DNOM. Pseudopolarographic measurements were performed in order to define the deposition potential linked to the non-organic copper fraction and to distinguish the different copper fractions, i.e. the labile part, the more or less strongly-complexed part, or the inert part. Analysis of DNOM interactions with $\mathrm{Cu}^{2+}, \mathrm{Ca}^{2+}$ and $\mathrm{H}^{+}$was performed by means of potentiometric titrations and pseudopolarographic measurements using logarithmic mode of $\mathrm{Cu}$ additions, as well as scanning of the $\mathrm{Ca}^{2+}$ concentration and $\mathrm{pH}$ at a constant $\mathrm{Cu}^{2+}$ concentration. Simultaneous fitting of all the data was carried out using PROSECE software to describe DNOM reactivity by the way of a discrete distribution of binding sites, characterised by sites densities and stability constants toward $\mathrm{Cu}^{2+}, \mathrm{Ca}^{2+}$ and $\mathrm{H}^{+}$.

Acidic properties of DNOM were correctly described by the use of four acidic sites. The total acidic site density (446.4 meq $\mathrm{mmol}_{\mathrm{C}}^{-1}$ ) was quite elevated, with mainly (60\%) carboxyliclike type. Copper binding properties of DNOM were modelled by two binding sites. The obtained densities and stability constants vs. 
$\mathrm{Cu}^{2+}$ were in accordance with the high reactivity of DNOM depicted towards copper in the literature. Simultaneous $\mathrm{Ca}^{2+}$ and $\mathrm{H}^{+}$competition effects toward $\mathrm{Cu}^{2+}$ binding, expected in marine waters, were taken into account for the first time, unlike previous studies focusing on trace metals. The strongest binding site ( $\log K_{\mathrm{CuL}}$ of 9.9) appeared not to be very $\mathrm{Ca}^{2+}$ specific $\left(\log K_{\mathrm{CaL}}\right.$ of 2.5$)$, which could be explained by its phenolic-like type ( $\mathrm{pKa}$ of 8.6), $\mathrm{Ca}^{2+}$ being probably more specifically bound by carboxylic-like sites (Lu and Allen, 2002). In contrast, for the second weaker binding site, copper $\left(\log K_{\mathrm{CuL}}\right.$ of 6.9) was more in competition with $\mathrm{Ca}^{2+}\left(\log K_{\mathrm{CaL}}\right.$ of 5.5).

This DNOM model was validated by being integrated to MINEQL code as it allowed a correct simulation of a titration experiment performed on the non-concentrated DNOM sample. It indicated that the concentration process did not strongly modify the DNOM reactivity. Therefore, the obtained binding parameters values could be used to depict DNOM role on $\mathrm{Cu}$ speciation in similar marine environments, for instance by the way of MOCO-SiAM3D, a contaminant transport model developed by IFREMER (Gonzalez et al., 2001).

The proposed analytical and modelling procedure is ready to be used to study different coastal marine and estuarine DNOM, coming from contrasting zones, to better understand DNOM role on metals speciation, and so their transport and bioavailability in these specific environments.

\section{Acknowledgements}

This work was realised thanks to the French research group MONALISA (convention number: 03/1214910/T) supported by the IFREMER institute.

The authors wish to thank the French Ministry of Education and Research, Provence-Alpes-Côte d'Azur regional council and the Ministry of Science, Education and Sports of the Republic of Croatia (through Grant No. 098-0982934-2720) for Ph.D. support and funding. We also thank the anonymous reviewers and the editor.

\section{References}

Branica, G., Lovrić, M., 1997. Pseudopolarography of totally irreversible redox reactions. Electrochimica Acta 42, 1247-1251.

Branica, M., Novak, D.M., Bubić, S., 1977. Application of anodic stripping voltammetry to determination of the state of complexation of traces of metal ions at low concentration levels. Croatica Chemica Acta 49, 539-547.

Bruland, K.W., Lohan, M.C., 2004. Controls of trace metals in seawater, vol. 6. In Holland, H.D., Turekian, K.K. (Eds.), Treatise on Geochemistry. Elsevier, Pergamon, pp. 23-47.

Buffle, J., 1988. Complexation reactions in aquatic systems. In: Analytical Chemistry. Ellis Horwood, Chichester.

Capodaglio, G., Scarponi, G., Toscano, G., Barbante, C., Cescon, P., 1995. Speciation of trace metals in seawater by anodic stripping voltammetry: critical analytical steps. Fresenius Journal of Analytical Chemistry 351, 386-392.

Chakraborty, P., Fasfous, I.I., Murimboh, J., Chakrabarti, C.L., 2007. Simultaneous determination of speciation parameters of $\mathrm{Cu}, \mathrm{Pb}, \mathrm{Cd}$ and $\mathrm{Zn}$ in model solutions of Suwannee River fulvic acid by pseudopolarography. Analytical and Bioanalytical Chemistry 388, 463-474.

Chau, Y.K., Lum-Shue-Chan, K., 1974. Determination of labile and strongly bound metals in lake water. Water Research 8, 383-388.

Croot, P.L., Moffett, J.W., Luther III, G.W., 1999. Polarographic determination of halfwave potentials for copper-organic complexes in seawater. Marine Chemistry 67, 219-232.

De Schamphelaere, K.A.C., Unamuno, V.I.R., Tack, F.M.G., Vanderdeelen, J., Janssen, C.R., 2005. Reverse osmosis sampling does not affect the protective effect of dissolved organic matter on copper and zinc toxicity to freshwater organisms. Chemosphere 58, 653-658.

Donat, J., Van Den Berg, C., 1992. A new cathodic stripping voltammetric method for determining organic copper complexation in seawater. Marine Chemistry 38 , 69-90.

Dudal, Y., Gerard, F., 2004. Accounting for natural organic matter in aqueous chemical equilibrium models: a review of the theories and applications. EarthScience Reviews 66, 199-216.

Garnier, C., Mounier, S., Benaim, J.Y., 2004a. Metal logarithmic scale titration as a tool for complexing ligand distribution determination: an application by DPASV. Environmental Technology 25, 589-599.
Garnier, C., Pižeta, I., Mounier, S., Benaim, J.Y., Branica, M., 2004b. Influence of the type of titration and of data treatment methods on metal complexing parameters determination of single- and multi-ligand systems measured by stripping voltammetry. Analytica Chimica Acta 505, 263-275.

Garnier, C., Mounier, S., Benaim, J.Y., 2004c. Influence of dissolved organic carbon content on modelling natural organic matter acid-base properties. Water Research 38, 3685-3692.

Garnier, C., Pižeta, I., Mounier, S., Cuculić, V., Benaim, J.Y., 2005. An analysis of distinguishing composite dissolved metal-ligand systems measurable by stripping voltammetry. Analytica Chimica Acta 538, 263-271.

Gonzalez, J.L., Thouvenin, B., Dange, C., Fiandrino, A., Chiffoleau, J.F., 2001. Modeling of Cd speciation and dynamics in the Seine estuary (France). Estuaries 24, 10411055.

Hamilton-Taylor, J., Postill, A.S., Tipping, E., Harper, M.P., 2002. Laboratory measurements and modelling of metal-humic interactions under estuarine conditions. Geochimica et Cosmochimica Acta 66, 403-415.

Herbelin, A.L., Westall, J.C., 1999. FITEQL 4.0: A Computer Program for Determination of Chemical Equilibrium Constants from Experimental Data, Report 99-01, Department of Chemistry, Oregon State University, Corvallis.

Hirose, K., 1994. Conditional stability constants of metal complexes of organic ligands in sea water: past and present, and a simple coordination chemistry model. Analytica Chimica Acta 284, 621-634.

Hirose, K., 2007. Metal-organic matter interaction: ecological roles of ligands in oceanic DOM. Applied Geochemistry 22, 1636-1645.

Huguet, A., Innocent, C., Roux De Balmann, H., Parlanti, E., 2006, personnal communication. In: Frimmel, F.H. Abbt-Braun, G. (Eds.), Proceedings of the 13th Meeting of the International Humic Substances Society, July 30-August 4, Universität Karlsruhe, Karlsruhe, Germany, p. 373.

Iglesias, A., López, R., Fiol, S., Antelo, J.M., Arce, F., 2003. Analysis of copper and calcium-fulvic acid complexation and competition effects. Water Research 37 , 3749-3755.

Kinniburgh, D.G., Milne, C.J., Benedetti, M.F., Pinheiro, J.P., Filius, J., Koopal, L.K., Van Riemsdijk, W.H., 1996. Metal ion binding by humic acid: application of the NICA-Donnan model. Environmental Science and Technology 30, 1687-1698.

Kogut, M.B., Voelker, B.M., 2001. Strong copper-binding behavior of terrestrial humic substances in seawater. Environmental Science and Technology 35 , $1149-1156$

Lenoble, V., Garnier, C., Masion, A., Ziarelli, F., Garnier, J.M., 2008. Combination of ${ }^{13} \mathrm{C} /{ }^{113} \mathrm{Cd}$ NMR, potentiometry, and voltammetry in characterizing the interactions between $\mathrm{Cd}$ and two models of the main components of soil organic matter. Analytical and Bioanalytical Chemistry 390, 749-757.

Louis, Y., Cmuk, P., Omanović, D., Garnier, C., Lenoble, V., Mounier, S., Pižeta, I., 2008. Speciation of trace metals in natural waters: the influence of an adsorbed layer of natural organic matter (NOM) on voltammetric behaviour of copper. Analytica Chimica Acta 606, 37-44.

Lu, Y., Allen, H.E., 2002. Characterization of copper complexation with natural dissolved organic matter (DOM) - link to acidic moieties of DOM and competition by Ca and Mg. Water Research 36, 5083-5101.

Luther III, G.W., Rozan, T.F., Witter, A., Lewis, B., 2001. Metal-organic complexation in the marine environment. Geochemical Transactions. 2, 65-74.

Nicolau, R., Louis, Y., Omanović, D., Garnier, C., Mounier, S., Pižeta, I., 2008. Study of interactions of concentrated marine dissolved organic matter with copper and zinc by pseudopolarography. Analytica Chimica Acta 618, 35-42.

Raspor, B., Nürnberg, H.W., Valenta, P., Branica, M., 1980. Kinetics and mechanism of trace metal chelation in sea water. Journal of Electroanalytical Chemistry 115 , 293-308.

Rossi, N., Jamet, J.-L., 2008. In situ heavy metals (copper, lead and cadmium) in different plankton compartments and suspended particulate matter in two coupled Mediterranean coastal ecosystems (Toulon Bay, France). Marine Pollution Bulletin 56, 1862-1870.

Ružić, I., 1982. Theoretical aspects of the direct titration of natural waters and its information yield for trace metal speciation. Analytica Chimica Acta 140, 99113.

Scatchard, G., 1949. The attraction of proteins for small molecules and ions. Annals of New York Academy of Sciences 51, 660-672.

Sposito, G., 1981. Trace metals in contaminated waters. Environmental Science and Technology 15, 396-403.

Sunda, W.G., Tester, P.A., Huntsman, S.A., 1987. Effects of cupric and zinc ion activities on the survival and reproduction of marine copepods. Marine Biology 94, 203-210.

Tipping, E., Lofts, S., Lawlor, A.J., 1998. Modelling the chemical speciation of trace metals in the surface waters of the Humber system. The Science of the Total Environment 210, 63-77.

Town, R.M., Filella, M., 2002. Implications of natural organic matter binding heterogeneity on understanding lead(II) complexation in aquatic systems. The Science of the Total Environment 300, 143-154.

Town, R.M., van Leeuwen, H.P., 2006. Comparative evaluation of scanned stripping techniques: SSCP vs. SSV. Croatica Chemica Acta 79, 15-25.

Van der Lee, J., De Windt, L., 2000. CHESS Tutorial and Cookbook. User's Guide Nr. LHM/RD/99/05, CIG-École des Mines de Paris, Fontainebleau, France.

Van Leeuwen, H.P., Town, R.M., Buffle, J., Cleven, R.F.M.J., Davison, W., Puy, J., Van Riemsdijk, W.H., Sigg, L., 2005. Dynamic speciation analysis and bioavailability of metals in aquatic systems. Environmental Science and Technology 39, 85458556.

Vetter, T.A., Perdue, E.M., Ingall, E., Koprivnjak, J.F., Pfromm, P.H., 2007. Combining reverse osmosis and electrodialysis for more complete recovery of dissolved 
organic matter from seawater. Separation and Purification Technology 56, 383387.

Wells, M.L., Kozelka, P.B., Bruland, K.W., 1998. The complexation of "dissolved" Cu, $\mathrm{Zn}, \mathrm{Cd}$ and $\mathrm{Pb}$ by soluble and colloidal matter in Narragansett Bay, RI. Marine Chemistry 62, 203-217.

Westall, J.C., Zachary, J.L., Morel, F., 1976. MINEQL, a computer program for the calculation of chemical equilibrium composition of aqueous systems. R.M.
Parsons laboratory technical note 18. Massachusetts Institute of Technology, Cambridge, MA.

Woolard, C.D., Linder, P.W., 1999. Modelling of the cation binding properties of fulvic acids: an extension of the RANDOM algorithm to include nitrogen and sulphur donor sites. Environmental Science and Technology 226, 3546. 